\title{
NILAI NASIONALISME PADA BUKU TEKS BAHASA INDONESIA SMP KELAS VII KURIKULUM 2013 EDISI REVISI 2017 (KAJIAN SEMIOTIK CHARLES SANDERS PIERCE)
}

\author{
Linda Nur Alfiana \\ SMP PGRI 8 Surabaya \\ lindanur.pbsi@gmail.com
}

\begin{abstract}
ABSTRAK
Penelitian ini bertujuan mendeskripsikan nilai nasionalisme dalam wujud cinta tanah air dan patriotisme pada buku teks Bahasa Indonesia SMP kelas VII. Penelitian ini merupakan penelitian kualitatif. Sumber data penelitian adalah buku teks Bahasa Indonesia SMP Kelas VII kurikulum 2013 edisi revisi 2017. Analisis data dilakukan dengan menggunakan triadic makna semiotik Charles yaitu sign, object, dan interpretan. Berdasarkan hasil penelitian nilai nasionalisme yang ditemukan dalam buku Bahasa Indonesia SMP kelas VII Kurikulum 2013 Edisi Revisi 2017 berupa data verbal dan visual. Data verbal dan visual yang ditemukan meliputi nilai nasionalisme dalam wujud cinta tanah air dan patriotisme. Nilai nasionalisme dalam wujud cinta tanah air disajikan dalam bentuk sikap mencintai dan menjaga keindahan alam Indonesia, mencintai dan melestarikan budaya Indonesia, mencintai flora dan fauna Indonesia, mencintai dan melestarikan kuliner Indonesia, dan mewujudkan lingkungan sehat. Nilai nasionalisme dalam wujud patriotisme disajikan dalam bentuk sikap rela berkorban, sikap toleransi, dan sikap pantang menyerah.
\end{abstract}

Kata kunci: nilai nasionalisme, buku teks, semiotik charles.

\section{ABSTRACT}

This study aims to describe the value of nationalism in the form of love of the homeland and patriotism in the Indonesian Language textbook of Class VII Middle School. This research is a qualitative research. The source of the research data is the Indonesian Language Textbook of Class VII Middle School 2013 Revised Edition on 2017. The data analysis was done using the triadic semiotic meaning of Charles namely sign, object, and interpretan. Based on the results of the study, the nationalism values found in the Indonesian Language textbook of Class VII Middle School, curriculum 2013, revised edition of 2017, in the form of verbal and visual data. Verbal and visual data found was include the value of nationalism in the form of loving the homeland and patriotism. The value of nationalism in the form of loving the homeland is presented in the form of an attitude of loving and maintaining the natural beauty of Indonesia, loving and preserving Indonesian culture, loving Indonesian flora and fauna, loving and preserving Indonesian culinary, and realize a healty environtment. While the value of nationalism in the form of an attitude of patriotism is presented in the form of a willingness to sacrifice, tolerance, and the attitude of never giving up.

Keywords: nasionalism value, text book, semiotic charles. 


\section{PENDAHULUAN}

Nasionalisme bagi bangsa Indonesia merupakan pondasi berdirinya sebuah negara. Sebagai salah satu negara bekas jajahan, Indonesia memperjuangkan kemerdekaannya melalui pertaruhan nyawa dan pertumpahan darah para pahlawan. Nasionalisme telah menghantarkan Indonesia pada kemerdekaan dan menuju kehidupan yang lebih layak sesuai dengan kondisi Negara Indonesia yang menjunjung adat dan kebudayaan. Nasionalisme mengajarkan kepada kita untuk mencintai bangsa dan negara dengan sepenuh hati dan segala apa yang dimilikinya. Dengan adanya sikap tersebut akan melahirkan semangat dan sikap patriotisme yang tangguh untuk menjaga persatuan dan kesatuan Negara Indonesia. Pengalaman sejarah telah menjadikan nasionalisme tertanam dalam jiwa Negara Indonesia, maka dari itu nasionalisme harus tetap dijaga dan dilestarikan.

Diperlukan wawasan kebangsaan untuk membawa bangsa Indonesia ke arah kehidupan yang lebih maju. Wawasan kebangsaan yang dianut bangsa Indonesia adalah wawasan yang berlandaskan Pancasila yaitu wawasan kebangsaan yang berlandaskan Ketuhanan Yang Maha Esa, yang berlandaskan budi pekerti, akhlak dan spiritual. Nasionalisme sebagai perspektif nilai-nilai pancasila, cita-cita luhur bangsa Indonesia yang tercantum dalam UUD 1945 dan butir-butir pengamalan pancasila. Akan tetapi, dalam pengamalannya perilaku masyarakat Indonesia belum mencerminkan nilai-nilai nasionalisme seperti yang diharapkan. Hal ini disebabkan pemahaman masyarakat terkait nilai-nilai nasionalisme yang minim sehingga belum dapat mencerminkan nilai nasionalisme seperti apa yang tertuang dalam butir pancasila. Dalam mewujudkan cita-cita luhur bangsa Indonesia diperlukan tekad dan kesungguhan.

Dunia pendidikan selalu dikaitkan dengan penanaman nilai-nilai, salah satunya nilai-nilai nasionalisme. Penanaman nilai-nilai diperlukan sebagai suatu upaya masyarakat Indonesia dalam mewujudkan nilai-nilai yang berorientasi pada Pancasila. Proses penanaman nilai dalam pendidikan bersifat dinamis mengikuti perkembangan zaman. Didalam perjalanannya pendidikan telah mengalami beberapa perubahan dan inovasi terhadap kurikulum untuk mencapai tujuan dari pendidikan nasional yang tertuang dalam Undang-undang Sistem Pendidikan Nasional Nomor 20 tahun 2003. 
Salah satu bentuk inovasi pendidikan yang dilakukan adalah penanaman pendidikan karakter. Inovasi pendidikan ini terus dilakukan untuk memperbaiki proses pendidikan dan menentukan tolok ukur pendidikan yang tepat. inovasi yang dilakukan saat ini terfokus pada penanaman pendidikan karakter yang memuat nilai nasionalisme melalui berbagai proses pendidikan yang berdampingan dengan kompetensi. Program pendidikan karakter dilakukan melalui internalisasi nilai-nilai nasionalisme salah satunya melalui buku teks mata pelajaran Bahasa Indonesia.

Buku teks sebagai sumber belajar menjadi salah satu hal pokok dalam mendukung pembelajaran. Buku teks sengaja dirancang secara cermat oleh pakar pendidikan sejalan dengan diberlakukannya kurikulum 2013. Pada kurikulum ini peserta didik diharapkan dapat menggali sendiri materi yang dipelajari dan tidak menjadikan guru sebagai salah satu sumber informasi, melainkan menjadikan guru sebagai fasilitator.

Berdasarkan realita yang ada, penanaman nilai nasionalisme sebagai upaya pengamalan pendidikan karakter di sekolah selama ini baru menyentuh pada tingkatan pengenalan norma atau nilai-nilai, belum pada tingkatan internalisasi dan tindakan nyata dalam kegiatan sehari-hari. Sebagai media pembelajaran, buku teks berfungsi untuk membantu dan mempermudah kegiatan belajar mengajar guru dan siswa. Buku teks sebagai media yang efektif dalam menyampaikan informasi, pengetahuan, dan pendidikan karakter kepada peserta didik.

Yunianti (2013) dalam penelitiannya menggunakan teori semiotika Charles Sanders Pierce. Hasil penelitian menyebutkan bahwa dalam buku pelajaran kebaharian SMA/SMK ditemukan bentuk-bentuk Nasionalisme Maritim berupa data verbal dan data visual. Data verbal menjelaskan bahwa laut sebagai simbol identitas bangsa Indonesia berdasarkan kondisi wilayah Indonesia sebagai Negara kepulauan. Sehingga tercertus deklarasi bukanen dan seruan sunda kelapa sebagai implementasi tentang laut nusantara yang harus kita jaga, pelihara dan lestarikan. Sedangkan data visual sebagai data pendukung materi kebaharian menjelaskan ilustrasi gambar yang ditampilkan tidak menunjukkan Nasionalisme maritim melainkan bentuk-bentuk budaya asing sebagai westernisai.

Normawati (2015) menyebutkan bahwa nilai pendidikan karakter dalam buku teks Bahasa Indonesia SMP yang dipakai di Daerah Istimewa Yogyakarta ditemukan 
dalam lima hubungan karakter. Kelima nilai pendidikan karakter ini diperoleh berdasarkan panduan nilai pendidikan karakter dari Kemendiknas (2010:16) sekaligus juga pada Standar Kompetensi Lulusan (SKL), yakni nilai karakter manusia terhadap Tuhan, diri sendiri, sesama, lingkungan, dan bangsa.diantara kelima hubungan karakter yang ada dalam buku teks pelajaran, hubungan karakter manusia terhadap Tuhan yang paing sedikit ditemukan. Sebaliknya, karakter manusia terhadap diri sendiri dan sesama lebih intensif muncul. Hal ini menyiratkan bahwa penulis ingin menekankan pada aspek manusia yang memiliki kehidupan pribadi dan kehidupan sosial.

Dalam penelitian ini, peneliti menggunakan buku teks Bahasa Indonesia kelas VII kurikulum 2013 edisi revisi 2017 yang diterbitkan oleh Kementerian Pendidikan dan Kebudayaan Republik Indonesia. Buku ini merupakan buku pegangan wajib yang digunakan guru dan peserta didik dalam pembelajaran. Berdasarkan hal tersebut peneliti memilih buku ini untuk mengupas bentuk nilai nasionalisme pada buku teks yang berkesinambungan dengan program pendidikan karakter yang dilaksanakan oleh pemerintah. Adapun tujuan penelitian ini adalah untuk mendeskripsikan wujud cinta tanah air dan wujud patriotisme menggunakan kajian semiotikan Charles Sanders Pierce.

\section{METODE PENELITIAN}

Metode penelitian ini adalah metode penelitian deskriptif kualitatif dengan menggunakan teori semiotik Charle Sanders Pierce. Dalam penelitian ini, peneliti menjadi human instrument (Satori, 2009:61) yang menetapkan fokus penelitian, melakukan pengumpulan data, menganalisis data dan membuat kesimpulan. Data dalam penelitian ini berupa data verbal dan visual yang menunjukkan nilai-nilai nasionalisme yang ada pada buku teks Bahasa Indonesia SMP/MTs kelas VII edisi revisi 2017 terbitan Kementerian Pendidikan dan Kebudayaan Republik Indonesia.

Teknik pengumpulan data dilakukan dalam tiga langkah kegiatan yaitu, penyediaan data, analisis data, dan penyajian hasil analisis. Penyediaan data terdiri dari kegiatan yaitu mengumpulkan, memilih, memilah dan menata (Muhammad, 2010:199). Kegiatan mengumpulkan daya ditandai oleh pencatatan, kemudian 
dilanjutkan dengan proses memilih, memilah dan menata data berdasarkan konteks penelitian.

Kriteria keabsahan data dalam penelitian ini menggunakan derajat kepercayaan (credibility) terhadap penemuan nilai nasionalisme dan dibuktikan dengan teknik ketekunan pengamatan terhadap isi teks dalam buku.

Teknik analisis data dalam penelitian ini, menggunakan teori segitiga makna Charles yaitu sign, object, dan interpretan (Vera, 2015:21). Dalam penelitian ini cara yang digunakan penulis dalam meneliti nilai nasionalisme yang terdapat pada buku teks yaitu dengan menggunakan teknik catat, baca, dan simak. Peneliti menggunakan teori semiotika karena ingin melihat bentuk-bentuk nasionalisme yang disajikan dalam buku teks Bahasa Indonesia SMP kelas VII.

Kodifikasi merupakan proses atau cara mengelompokkan data untuk dianalisis menurut kelompok data. Miles dalam Afrizal (2014:178) menyatakan kodifikasi data merupakan tahap pengkodingan data, yaitu peneliti memberikan nama terhadap hasil penelitian. hasil kegiatan yang diperoleh merupakan tema-tema atau klasifikasi baru dari peneliti. Setelah itu, dilakukan proses penyajian data. Dalam hal ini disajikan temuan penelitian berupa pengelompokan atau pengkategorian.

\section{PEMBAHASAN}

Dari hasil penelitian pada buku teks Bahasa Indonesia SMP Kelas VII kurikulum 2013 edisi revisi 2017 ditemukan nilai nasionalisme dalam wujud cinta tanah air dan wujud patriotisme yang disajikan dalam bentuk data verbal dan data visual. Wujud cinta tanah air yang ditemukan dalam buku teks Bahasa Indonesia terdiri atas lima bentuk sikap yang meliputi sikap yang meliputi sikap mencintai dan menjaga keindahan alam Indonesia, mencintai dan melestarikan budaya Indonesia, mencintai flora dan fauna Indonesia, mencintai dan melestarikan kuliner Indonesia dan mewujudkan lingkungan sehat. Sedangkan wujud patriotisme yang ditemukan dalam buku teks Bahasa Indonesia terdiri atas lima bentuk sikap yang meliputi sikap rela berkorban, sikap toleransi, dan sikap pantang menyerah. 
Wujud Cinta Tanah Air dalam Buku Teks Bahasa Indonesia SMP Kelas VII Edisi Revisi 2017

Berdasarkan hasil analisis pada buku teks ditemukan sikap mencintai dan menjaga keindahan alam Indonesia berupa data verbal dan visual. Sikap mencintai dan menjaga keindahan alam yang disajikan dalam bentuk visual dan verbal bertujuan agar peserta didik lebih mudah memahami maksud dan tujuan dari penulis. Wujud cinta tanah air disajikan dalam bentuk sikap mencintai dan menjaga keindahan alam Indonesia, mencintai dan melestarikan budaya Indonesia, mencintai flora dan fauna Indonesia, mencintai dan melestarikan kuliner Indonesia, dan mewujudkan lingkungan sehat.

\section{Mencintai dan menjaga keindahan Alam Indonesia}

Indonesia memiliki kondisi geografis dan iklim yang tepat, sehingga tidak mengherankan apabila Indonesia memiliki berbagai keindahan alam yang tersaji dalam gugusan pulau, pantai, gunung, hutan dan sebagainya. Oleh sebab itu, Indonesia mendapat julukan Heaven Earth dimata dunia. Berdasarkan hasil analisis wujud cinta tanah air dalam bentuk sikap mencintai dan menjaga keindahan alam Indonesia tersaji dalam bentuk verbal dan visual, dalam bentuk verbal ditemukan 12 data dan dalam bentuk visual ditemukan 3 data. Sikap mencintai dan menjaga keindahan alam Indonesia ini tersaji dalam teks deskripsi, teks laporan hasil observasi, surat pribadi dan surat dinas, dan resensi fiksi dan nonfiksi. Jenis teks tersebut dijabarkan sebagai bentuk upaya penanaman sikap nasionalisme pada peserta didik. Berikut merupakan salah sampel bentuk sikap mencintai dan menjaga keindahan Alam yang tersaji dalam teks deskripsi.

Teks deskripsi dalam buku teks disajikan dalam bentuk visual dan verbal. Gambar disajikan dalam buku teks agar siswa lebih memahami konsep dari teks deskripsi yang bertujuan untuk menggambarkan suatu objek secara rinci. Meliputi hal yang dilihat, didengar, dan dirasakan secara objektif. Dengan disajikan gambar pada teks deskripsi diharapkan pembaca seolah-olah dapat melihat, mendengar dan merasakan hal digambarkan dalam teks.

Pada teks deskripsi penulis menyajikan gambar pemandangan pantai disajikan dalam teks deskripsi yang terfokus pada barisan pohon kelapa. Indonesia mendapat julukan negara nyiur hal ini disebabkan banyaknya pohon kelapa yang tumbuh 
disepanjang bibir pantai. Pohon kelapa identik dengan pohon seribu manfaat dan menyimpan filosofi hidup yang sangat bermanfaat dapat direfleksikan dalam kehidupan manusia. Batangnya yang berdiri kokoh dan daun yang rimbun mengurangi terik matahari, daunnya melambai saat tersapu semilir angin. Hal ini dapat direfleksikan dalam kehidupan bernegara, batang yang kokoh melambangkan niat dan tekad yang bulat untuk menjaga dan mencintai bangsa Indonesia dengan segenap jiwa raga, sedangkan daunnya yang berwarna hijau melambangkan kesejukan yang menghadirkan kedamaian pada suatu negara.

Pohon kelapa yang berdiri berjajar merepresentasikan kehidupan bermasyarakat dalam negara. Warga negara hidup saling berdampingan saling menghormati, menghargai, menyayangi, dan menjaga satu sama lain tidak memperdulikan latar belakang agama, budaya maupun suku agar tercipta kedamaian dan kesatuan. Dengan merealisasikan sikap ini dalam bermasyarakat maka secara tidak langsung telah mengamalkan cita-cita bangsa Indonesia terkait persatuan yang tertuang dalam Pancasila. Selain menanamkan filosofi pohon kelapa kepada pesera didik, dengan disajikannya teks ini peserta didik diharapkan dapat lebih mencintai destinasi wisata yang ada di Indonesia dan sebagai bentuk apresiasi atas keindahan alam yang berlimpah di Negara Indonesia.

\section{Mencintai dan Melestarikan Budaya Indonesia}

Kebudayaan merupakan hasil aktivitas manusia yang berlangsung secara terus menerus tanpa bermuara pada satu titik keseimbangan dalam waktu sementara atau selamanya (Faruk, 2018: 3). Kebudayaan sebagai sesuatu yang manusiawi memiliki sifat sosial dan historis memiliki keterikatan pada ruang dan waktu. Apabila dilihat dari sudut pandang strukturalisme-fenomenologis kebudayaan menjadi sebuah tatanan yang memberikan keseimbangan "sense of order", keteraturan dan ketertaatan. (Faruk, 2018:9).

Berdasarkan hasil analisis pada buku teks ditemukan sikap mencintai dan melestarikan budaya Indonesia yang disajikan dalam bentuk visual dan verbal. Sikap mencintai dan melestarikan budaya Indonesia yang disajikan dalam bentuk visual dan verbal bertujuan agar peserta didik lebih mudah memahami maksud dan tujuan dari penulis. Kondisi geografis negara Indonesia yang terdiri dari pulau-pulau menjadi 
keuntungan tersendiri bagi kebudayaan dan adat yang berkembang Indonesia, sehingga Indonesia memiliki banyak kebudayaan dan adat yang tersebar hingga pelosok daerah.

Menjaga dan melestarikan kekayaan pada adat dan budaya warisan leluhur yang tersebar di seluruh daerah di Indonesia bukanlah perkara mudah. Jika pemerintah dan rakyat Indonesia tidak melakukan langkah proaktif secara bersama untuk menjaganya maka, tidak mustahil apabila adat dan budaya yang ada di Indonesia dapat hilang atau bahkan di klaim oleh negara lain. Salah satu langkah aktif yang saat ini ditempuh oleh pemerintah untuk menjaga dan melestarikan kebudayaan yakni melalui pendidikan. Melalui pendidikan pemerintah ingin menanamkan rasa nasionalisme pada peserta didik untuk turut serta menjaga dan melestarikan adat dan budaya warisan leluhur, sehingga tidak hilang seiring berjalannya waktu.

Berdasarkan hasil analisis sikap menjaga dan melestarikan budaya tersaji dalam teks deskripsi dan puisi rakyat tersaji dalam bentuk verbal dan visual, dalam bentuk verbal ditemukan 8 data dan dalam bentuk visual ditemukan 7 data. Sikap menjaga dan melestarikan budaya tersaji dalam teks deskripsi dan puisi rakyat. Berikut merupakan sampel bentuk sikap menjaga dan melestarikan budaya yang tersaji dalam kutipan teks berikut.

“...Memasuki Rantepao akan kita temui Tongkonan berjajar rapi dan indah seakan menyambut dengan ramah setiap pengunjung yang datang."

Indonesia sebagai negara kepulauan terbesar diberkahi dengan keanekaragaman, mulai dari agama, bahasa, tradisi, adat istiadat, pakaian sampai bangunan yang membuat indonesia dinobatkan sebagai Negara Budaya. Indonesia juga mempunyai banyak suku yang beragam mulai dari sabang sampai merauke salah satunya adalah suku Toraja. Keberagaman budaya Indonesia ini tidak dapat dipungkiri karena letak geografis negara Indonesia sebagai negara kepulauan yang terdiri atas berbagai etnik. Tiap-tiap etnik memiliki adat istiadat dan kebudayaan sebagai identitas kelompokmya. Kondisi geografis yang berbeda di setiap daerah menjadi salah satu latar keberagaman rumah adat yang ada, salah satunya yaitu Rumah Tongkonan.

Rumah Tongkonan ini adalah salah satu keberagaman budaya yang ada di Indonesia. Tongkonan merupakan rumah adat masyarakat Toraja, Tongkonan berasal 
dari kata tongkon yang memiliki arti duduk bersama-sama. Tongkonan terbuat dari kayu dengan kualitas terbaik, bagian Tongkonan yang paling terlihat mencolok adalah atap yang berbentuk seperti perahu. Bagian ini menjadi pengingat bahwa leluhur mereka menggunakan perahu untuk sampai di Sulawesi.

"Tongkonan tersebut didekorasi dengan sejumlah tanduk kerbau yang ditancapkan di bagian depan rumah adat. Di setiap bangunan bagian depan terdapat deretan tanduk kerbau".

Tanduk kerbau yang ditancapkan pada tiang rumah Tongkonan menjadi simbol untuk menunjukkan status sosial pemilik rumah. Kerbau bagi masyarakaat Toraja merupakan lambang kebangsawanan, karena satu kerbau hitam memiliki harga 60 juta per ekor, sedangkan kerbau belang memiliki harga mulai 600 juta - 1 miliar.

Rumah adat Tongkon menjadi salah satu ikon suku Toraja selain upacara pemakamannya. Suku Toraja termasyhur karena rumah adatnya yang unik dan cantik. Oleh sebab itu, kita wajib menjaga dan melestarikan budaya yang diwariskan oleh leluhur agar tidak punah maupun diakui oleh negara lain.

\section{Mencintai Flora Dan Fauna Indonesia}

Berdasarkan hasil analisis pada buku teks ditemukan sikap mencintai flora dan fauna Indonesia yang disajikan dalam bentuk visual. Indonesia memiliki kondisi geografis dan iklim yang tepat bagi flora dan fauna yang ada, sehingga tidak mengherankan apabila Indonesia mendapat julukan Heaven Earth dimata dunia. Tidak hanya keindahan flora yang menjadi pemikat mata saat kita memandangnya, ada berbagai jenis spesies fauna yang hidup di Indonesia. Sikap mencintai flora dan fauna Indonesia dapat dilihat dalam teks cerita fantasi dan teks laporan hasil observasi.

Pada teks cerita fantasi disajikan sebuah buku cerita fantasi yang mengangkat tema hewan endemik Indonesia yaitu komodo, cerita fantasi ini muncul berdasarkan pengamatan penulis pada hewan komodo dan Pulau Komodo. Komodo diklasifikasikan sebagai hewan predator yang memiliki postur tubuh kuat dan besar, berdasarkan hal ini penulis ingin menanamkan nilai nasionalisme yang diilhami dari perilaku komodo. Sikap nasionalisme yang kuat dan tangguh direpresentasikan 
melalui perilaku hewan komodo. Apabila hewan saja memiliki insting untuk untuk menjaga dan mempertahankan wilayahnya maka manusia sebagai makhluk berkal yang memiliki kemampuan berpikir hendaknya dapat melakukan hal yang sama. Sikap nasionalisme yang digambarkan pada hewan komodo pada sikap aparatur negara yang bertugas untuk menjaga dan memberi rasa aman bagi seluruh rakyat Indonesia.

Tidak diragukan lagi sikap bela negara yang ada pada jiwa TNI dan POLRI mereka selalu siap sedia menjaga persatuan dan kesatuan Negara Indonesia. Mereka memiliki sikap yang tegas saat menjalankan tugas mempertahankan wilayah negara akan tetapi, mereka tetaplah manusia sosial yang hidup berdampingan dalam masyarakat karena mereka meyakini bahwa mereka kuat bersama rakyat. Untuk mempertahankan sebuah negara Tentara Negara Indonesia (TNI) dan Polisi RI (POLRI) memiliki sikap siap sedia berkorban untuk menjaga keutuhan serta mempertahankan stabilitas Negara Indonesia. Jiwa mereka buas terhadap musuh yang ingin merusak kedamaian dan persatuan yang ada di Negara Indonesia. Sikap ini pula yang ada pada hewan komodo saat dirinyan dan wilayahnya merasa terancam maka mereka segera melakukan perlawanan untuk mempertahankan wilayah dan keselamatan diri.

Didalam habitatnya komodo hidup berkelompok hal ini merepresentasikan kerukunan yang ada di Negara Indonesia yang memiliki warga negara yang heterogen. Tidak memperdulikan ras dan agama mereka tetap menjaga perdamaian demi persatuan bangsa Indonesia.

\section{Sikap mencintai dan melestarikan kuliner Indonesia}

Berdasarkan hasil analisis pada buku teks ditemukan sikap mencintai dan melestarikan kuliner Indonesia yang disajikan dalam bentuk gambar. Indonesia memiliki berbagai macam kuliner dengan cita rasa khas masing-masing daerah yang tersebar di seluruh penjuru Indonesia. Penanaman sikap mencintai dan melestarikan kuliner Indonesia dapat dilihat dalam teks prosedur.

Sebagai negara yang terkenal dengan keragaman budayanya, Indonesia juga dikenal sebagai negara yang memiliki ragam makanan dan jajanan khas daerah yang mencirikan daerah bahkan identitas suku tertentu. Masakan tradisional merupakan 
salah satu kekayaan budaya Indonesia yang harus dilestarikan. Ada banyak jenis masakan dengan citarasa yang khas dan berbeda pada tiap-tiap daerah di Indonesia.

Pada materi teks prosedur penulis menampilkan sampul buku resep masakan nusantara. Buku resep masakan berisikan data-data dan petunjuk cara memasak. Selain itu buku resep masakan juga memuat tentang bahan dan alat serta bagaimana mengolah masakan. Buku resep masakan ini merupakan media untuk memperkenalkan dan memberikan informasi kepada masyarakat tentang resep masakan nusantara, juga berfungsi sebagai upaya pelestarian warisan budaya Indonesia. Dengan adanya media ini diharapkan semua lapisan masyarakat Indonesia bisa mengenal dan mencintai resep masakan nusantara yang khas dengan kekayaan rempah. Dengan adanya buku ini maka warisan budaya kuliner Nusantara dapat terjaga dan dilestarikan.

\section{Sikap mewujudkan lingkungan sehat}

Berdasarkan hasil analisis pada buku teks ditemukan sikap mencintai Indonesia melalui dunia kesehatan yang disajikan dalam bentuk gambar. Penanaman sikap mencintai Indonesia melalui dunia kesehatan dapat dilihat dalam teks prosedur yang menyajikan gambar kegiatan mencuci tangan menggunakan sabun pada air mengalir. Kegiatan mencuci tangan merupakan salah satu upaya untuk menjaga kebersihan agar terhindar dari penyakit.

Kemerdekaan Indonesia tidak terlepas dari perjuangan seluruh rakyat Indonesia yang sebagian dipelopori oleh dokter Indonesia 110 tahun silam yang telah menjabarkan nilai penting semangat nasionalis, tepatnya pada tanggal 20 Mei 1908 menjadi tanggal bersejarah bagi Perkumpulan Budi Utomo. Pada tanggal itu organisasi ini didirikan. Melihat penderitaan bangsa Indonesia pada masa penjajahan kolonial Belanda menggerakkan jiwa dan hati nurani organisasi yang beranggotakan para pemuda dan cendikia ini untuk melawan kezdoliman penjajah.

Kebanyakan anggota dari organisasi ini berprofesi sebagai dokter dan mahasiswa kedokteran di School yoy Opleiding van Indlandsche Artsen (STOVIA). Dr. Tjipto Manoenkoesoemo, dr. Wahidin Soedirohoesodo, dr. Soetomo merupakan tokoh 1908 yang berprofesi sebagai dokter dan akademisi di STOVIA. Berdasarkan latar belakang tersebut setiap 20 Mei diperingati sebagai hari kesehatan nasional, 
Kemenkes membentuk program Nusantara Sehat sebagai realisasi penguatan pelayanan kesehatan untuk mewujudkan program Nawacita yang telah dirancang oleh pemerintah. Diharapkan para tenaga medis dalam pelayanan kesehatan tetap melayani rakyat yang berlandaskan jiwa pengabdian dan dengan semangat nasionalis sebagai bakti kepada Ibu Pertiwi.

\section{Wujud Patriotisme dalam Buku Teks Bahasa Indonesia SMP Kelas VII Edisi Revisi 2017}

Berdasarkan hasil analisis pada buku teks ditemukan wujud patriotisme dalam bentuk data visual dan verbal. Sikap mencintai dan menjaga keindahan alam yang disajikan dalam bentuk visual dan verbal bertujuan agar peserta didik lebih mudah memahami maksud dan tujuan dari penulis. Wujud patriotisme disajikan dalam bentuk dalam bentuk sikap rela berkorban, sikap toleransi, dan sikap pantang menyerah.

\section{Sikap rela berkorban}

Berdasarkan hasil analisis pada buku teks ditemukan sikap rela berkorban yang disajikan dalam bentuk teks. Penanaman sikap rela berkorban dapat dilihat dalam teks cerita fantasi dan teks deskripsi dan teks cerita fantasi. Berikut merupakan sampel sikap rela berkorban yang tercantum dalam kutipan teks berikut.

"Mereka akan berjuang hingga titik darah penghabisan untuk membela tanah air tercinta."

Pada kutipan teks tersebut menggambarkan jiwa patriotisme serta sikap rela berkorban. Jiwa patriotisme serta sikap rela berkorban yang terkandung dalam teks ini divisualisakan dalam tokoh utama cerita yaitu Nataga. Nataga merupakan bentuk imajinasi penulis berdasarkan pengamatannya terhadap seekor komodo. Komodo merupakan fauna endemik Indonesia yang memiliki tubuh besar dan dikenal sebagai predator ini merepresentasikan kekuatan. Hal ini pula yang melatarbelakangi visualisasi pada teks yang menggambarkan sikap nasionalisme pada perjuangan Nataga, dengan tekad yang kuat untuk menjaga wilayahnya. Penyajian teks ini dalam buku diharapkan dapat menambah kecintaan dan rasa nasionalisme peserta didik terhadap Negara Indonesia, seperti yang dilakukan oleh Nataga dan pasukannya. 


\section{Sikap toleransi}

Berdasarkan hasil analisis pada buku teks ditemukan sikap toleransi yang disajikan dalam bentuk teks. Penanaman sikap toleransi dapat dilihat dalam teks cerita fantasi dan teks cerita fabel. Berikut merupakan sampel sikap toleransi yang tercantum dalam teks kutipan berikut.

"Saya mendengarkan teman yang berbeda pendapat dan meresponnya dengan santun."

Sikap toleransi merupakan sikap saling menghormati dan menghargai antarkelompok maupun antarindividu dalam masyarakat. Seperti pada kutipan teks diatas yang mencerminkan sikap toleransi. Sikap toleransi merupakan bekal utama dalam sebuah negara untuk menciptakan stabilitas dan menjaga nilai persatuan yang ada. Sikap ini menjadi sikap utama yang wajib dimiliki oleh bangsa Indonesia yang memiliki keberagaman suku, adat dan budaya, serta agama. Perbedaan ini akan menimbulkan perpecahan dan peperangan apabila tidak diiringi dengan sikap toleransi. Oleh sebab itu, toleransi bagi bangsa Indonesia merupakan hal mendasar yang wajib dimiliki oleh setiap warga negara. Penyajian teks ini dalam buku bertujuan untuk menanamkan sikap toleransi pada peserta didik, selain itu diharapkan denngan penyajian teks ini dapat menambah kecintaan dan rasa nasionalisme peserta didik terhadap Negara Indonesia.

\section{Sikap pantang menyerah}

Berdasarkan hasil analisis pada buku teks ditemukan sikap pantang menyerah yang disajikan dalam bentuk teks. Penanaman sikap pantang menyerah dapat dilihat dalam teks cerita fabel berikut.

"Para semut melihat Sang Belalang sembah menari, namun mereka tidak menghiraukan tarian indahnya itu karena mereka memiliki tugas yang sangat penting."

Fabel merupakan salah satu jenis teks yang menceritakan kehidupan hewan yang berperilaku menyerupai manusia. Cerita fabel juga dikenal sebagai cerita moral sebab pada cerita ini banyak nilai yang terkandung didalamnya. Berdasarkan kutipan teks 
diatas menginterpetasikan sikap yang dimiliki oleh semut. Serangga satu ini cenderung hidup di wilayah tropis dan hidup berkelompok, sehingga tidak mengherankan apabila semut identik sebagai serangga sosial. Selain sikap sosial semut juga termasuk hewan yang kuat, tangguh dan pantang menyerah meskipun ukuran tubuhnya relatif kecil. Walaupun serangga ini memiliki postur yang kecil akan tetapi tidak menyurutkan langkahnya dalam mencapai tujuan, hal ini tersirat dari kutipan teks diatas. Walaupun Semut melihat Belalang sembah menari dengan indah namun mereka tidak menghiraukannya karena masih memiliki tugas yang sangat penting.

Sebagai warga negara hendaknya menanamkan sikap pantang menyerah yang dapat diwujudkan dalam profesi yang dikuasai oleh masing-masing individu. Apabila dalam diri sudah tertanam sikap pantang menyerah maka sikap optimis otomatis menjadi pelengkap dalam setiap langkah.

\section{PENUTUP}

Buku teks pelajaran Bahasa Indonesia sebagai buku wajib pegangan guru dan peserta didik bukan hanya menyajikan materi kebahasaan dan kesastraan untuk mewujudkan sikap mahir berbahasa dan bersastra. Melainkan dalam buku teks memuat nilai dan mengintegrasikan nilai nasionalisme. Nilai pendidikan nasionalisme diwujudkan dalam bentuk cinta tanaha air dan patriotisme.

Wujud cinta tanah air disajikan dalam bentuk data verbal dan visual yang meliputi sikap mencintai dan menjaga keindahan alam Indonesia, mencintai dan melestarikan budaya Indonesia, mencintai flora dan fauna Indonesia, mencintai dan melestarikan kuliner Indonesia, dan mewujudkan lingkungan sehat.

Wujud patriotisme disajikan dalam bentuk data verbal dan visual yang meliputi sikap Wujud cinta tanah air disajikan dalam bentuk data verbal dan visual yang meliputi sikap rela berkorban, sikap toleransi, dan sikap pantang menyerah.

\section{DAFTAR PUSTAKA}

Kurniati, Hermin Dwi. 2016. Analisis Nilai-Nilai Pendididkan Karakter yang ada di Buku Pendidikan Kewarganegaraan Kelas III Terbitan Pusat Perbukuan Tahun 2008. Surakarta : Universitas Muhammadiyah Surakarta. 
Muhammad. 2011. Metode Penelitian Bahasa. Yogyakarta : Ar-Ruzz Media.

Normawati. 2015. Nilai Pendidikan Karakter dalam Buku Teks Pelajaran Bahasa Indonesia SMP di Daerah Istimewa Yogyakarta. Tesis dipublikasikan.

Satori, Djam'an., \& Komariah, Aan. 2017. Metodologi Penelitian Kualitatif. Bandung : Penerbit Alfabeta.

Sujinah., Fatin Idhoofiyatul, Karina, Dian R. 2017. Bahasa Indonesia Berwawasan Kebangsaan dan Bela Negara. Surabaya : UMSurabaya Publishing.

Vera, Nawiroh. 2014. Semiotika dalam Riset Komunikasi. Bogor : Ghalia Indonesia.

Yunianti, Nina., Mudzakkir, Moh (Eds). 2013. Nasionalisme Maritim (Anaisis Semiotika Buku Pelajaran Kebaharian SMS/SMK Hang Tuah). Surabaya : Universitas Negeri Surabaya. 